\title{
Doctoral Studies: Everything You Ever Wanted to Know (and Then Some)!
}

\author{
Moderators: Jennifer Branch-Mueller and Barbara Schultz-Jones \\ Panel Presenters: Melissa Johnston and Nancy Everhart, Ross Todd, Mihaela Banek Zorica \\ Mentors: Albert Boekhorst, Nancy Everhart, Karen Gavigan, Dianne Oberg, Ross Todd
}

\begin{abstract}
This session was designed to help teacher-librarian participants answer the questions, "Why might I consider doing a PhD program? What opportunities might it open for me?" The School Library Research SIG designed the session to help participants learn about opportunities for doctoral studies that prepare teacher-librarians for work in the academy and in school districts and government departments. Three panel presenters described various doctoral programs and related professional development opportunities in school librarianship. After the panel presentations, several faculty advisors provided information and advice for participants in a "speed-mentoring" session.
\end{abstract}

\section{PRESENTATIONS \\ Things to Consider When Making the Decision to Obtain a Doctorate Degree} Melissa Johnston and Nancy Everhart

Dr. Johnston is an Associate Professor in Educational Technology and Foundations, College of Education, University of West Georgia, USA. Dr. Everhart is a Professor in the College of Communication and Information, Florida State University, USA. This presentation on the process of undertaking a doctorate degree was led by a former doctorate student and her supervising professor to give two different perspectives on important aspects to consider.

There are many reasons why one might decide to embark on the journey to a doctorate degree. Some people are ready for a new challenge, some want to investigate an aspect of the profession, some want to educate future teacher librarians, and some want to advance their career. No matter what the reason, when making this decision there are many aspects to think about and questions to ask.

The starting point is to think about what you would like to ultimately do with the degree. Do you want to go into academia, stay in practice, or something else? There are two different options for a doctorate degree, a Doctorate in Education (EdD) and Doctorate of Philosophy (PhD). If you're interested in pursuing a career in academia, a $\mathrm{PhD}$, which is more oriented toward research and exploration of the field, is probably the way to go. But if you are looking to stay in practice and move into a leadership position an EdD might be a better option. Then it is about finding a program that offers the degree you want and expertise in your area of interest. Make sure to research universities and the faculty to ensure a good fit with your research interests.

Most doctorate programs are composed of coursework and dissertation credit hours. The coursework is to prepare you to find, analyze, and conduct research. Another question to ask and consider is the type of student you will be able to be. Can you be a full-time student? Or will you need to take courses part-time while you work? Doctoral programs are very challenging and require a great deal of time and this time commitment must also be considered in the decision and the impact on your life. Supportive family and friends can contribute to your success. Doctoral programs not only require a great time commitment, but can also entail a large financial commitment as well. Investigate the funding options available to you. Many programs have teaching or research assistantships available to students to assist with the financial obligations. There are also many fellowships and scholarships available.

\section{Doctoral Studies and Research at the University of Zagreb}

Mihaela Banek Zorica 
Dr. Banek Zorica is an Associate Professor in the Faculty of Humanities and Social Sciences at the University of Zagreb, Croatia. This presentation focused on the $\mathrm{PhD}$ program in Information and Communication Sciences at the University of Zagreb.

The $\mathrm{PhD}$ program in Information and Communication Sciences focuses on research in the field of information and communication sciences and covers the majority of branches within the scientific field (Archival and Documentation Science, Information systems and Informatiology, Library Science, Communication Sciences, Public Relations, Lexicography and Ecyclopaedistics, Museology, Mass Media, Journalism). The PhD program has a strong interdisciplinary potential, anchored in the breadth of the scientific field and other PhD programs conducted at the Faculty of Humanities and Social Sciences.

There are several research focuses covering different domains in Information and Communication sciences, two of which could be of the major interest for school librarians. First is the research focus "Information practices and knowledge in the digital environment" where we research following themes: epistemological perspectives in the context of digital sources, algorithms and participatory media; knowledge in participatory environments: knowledge as collective negotiation, dialogical approaches to creating knowledge; role of established "knowledge places" (e.g., libraries, archives, schools and universities, encyclopaedias, publishers, media) in new information/media ecologies; new information practices: social components, online identities; credibility and trust in digital environments; new models in information authority (singular vs. distributed/network models); information practices in different contexts (education, science, workplace, everyday life, democracy); investigating cognitive authority in online discussions; conceptual dimensions in critical information and media literacy; comparative analysis of educational practices in media and information literacy in EU countries.

The second research focus that could be of interest to school librarians is "Challenges of codification, sharing and creation of knowledge," covering themes such as: challenges and interconnectedness of user tagging and knowledge organization systems; visualization of scientific environments--mapping of different research areas, interdisciplinarity, linked data; recorded scientific communication in collaborative environments; collective knowledge dynamics; knowledge sharing and creation in collaborative environments; communities of practice and social networking; big data analysis and knowledge discovery in social networks.

The program is oriented towards regional students but is opened to international students as well. Instruction is both in Croatian and English, and the thesis can be written in English.

\section{The Research Invitational at Rutgers iSchool}

Ross J. Todd

Dr. Todd is Associate Professor and Chair, Department of Library and Information Science, School of Communication and Information, Rutgers University, USA.

Making a decision to engage in doctoral studies involves many interconnected aspects: choice of purpose and desired outcomes, choice of research focus, choice of institution, choice of supervisor and doctoral committee. These are significant and not necessarily easy decisions, and how do you make this choice, matching research goals, institution, program, and scholarly team. Simply put, it is likely you will be working closely with your doctoral supervisor and committee from anywhere between $4-8$ years. This presentation will outline one approach to helping you make a sound decision: The Rutgers iSchool Research Invitational. This scholarly daylong symposium has been held annually for the last three years in the Fall Semester. It is designed for those with completed Masters degrees and /or students in their final semester interested in undertaking a doctorate, and who might be interested in the considering the School's interdisciplinary PhD Program in Communication, Information and Library Studies. The focus of this symposium is to showcase iSchool master's student research interests (completed, in-progress and prospective work), to network with our iSchool community and to engage in some indepth discussions with scholars who might potentially be part of the doctoral student's dissertation committee. Participants attend a scheduled $\mathrm{PhD}$ Colloquium which showcases doctoral work of our current $\mathrm{PhD}$ students, have time to interact with current $\mathrm{PhD}$ students, and meet with the faculty. They present a research / scholarly poster which outlines their research interest, and engage in robust discussions about their potential research interests. Those wishing to participate complete an 
application, and these are considered by a juried panel of Rutgers SC\&I faculty. Those selected to participate and who attend are provided some generous travel reimbursement and up to two nights hotel accommodation. The presentation will outline specific details and provide a perspective on the value of this initiative.

\section{MENTORING SESSIONS \\ Advice for Choosing and Being Successful in a Doctoral Program}

Karen Gavigan

Dr. Gavigan is an Associate Professor in the School of Library and Information Science

College of Information and Communications, University of South Carolina, USA.

If you are considering a doctoral program, you should begin by doing your homework on

different programs: review the program website and check out its national rankings, read about the faculty credentials, and talk to graduates of the program.

Once you are admitted to the $\mathrm{PhD}$ program:

1. Talk to former PhD students at your university and get their recommendations for potential advisors.

2. Select a research topic that you are passionate about, not one that your advisor thinks you should be passionate about.

3. Become a member of a peer support group in your doctoral program.

4. Read everything you can (including dissertations) about your topic throughout your program of study, and begin working on your literature review early on.

5. Make as many assignments as possible relevant to your dissertation topic, so that you are building the steppingstones to your dissertation.

6. Grow your academic footprint by attending conferences or blogging in your field.

7. Sit in on other PhD students' defenses to get a feel for what yours will be like.

8. Have a layperson read your dissertation to ensure that it can be easily understood by a broad audience.

9. Grow thick skin for dissertation proposals / dissertation defenses. Your committee is only trying to help you make your work better!

10. Submit an article to a scholarly journal, in order to experience the process before you graduate.

\section{Advice on Developing a Research Focus}

Albert K. Boekhorst

Dr. Boekhorst is an information scientist who worked at the Universiteit van Amsterdam, Mediastudies in the Netherlands and is a research fellow at the University of Pretoria in South Africa.

Have a clear simple 'academic question', related to general theories.

To come to this, use the 'funnel model' by starting with a very general 'problem' and make clear choices to come to your exact question.

Then rethink if you can answer your question with the outcomes of the research.

\section{Choosing a Doctoral Supervisor}

Dianne Oberg

Dr. Oberg is Professor Emerita, Faculty of Education, University of Alberta, Canada.

My own doctoral supervisor taught me the importance of choosing a doctoral supervisor who has expectations close to yours in relation to the closeness of the supervisory relationship. She and I both preferred to have a more distant and formal relationship, rather than a close and informal one. After agreeing to some basic goals and guidelines, I worked quite independently. I sent her my work when I decided I was ready for her feedback and advice. She was quick to get back to me; we met to discuss her feedback and advice; and then I went away to work on the next piece of work on my own.

My experience as a graduate coordinator taught me that students should not hesitate to talk with their supervisor about the process and content of supervision. If either is not working for the student, he or she should definitely look for a new supervisor (and should do so, following the protocols laid down by the university for this kind of change) — sooner, rather than later! 


\section{What is a PhD Program of Study Really Like?}

Nancy Everhart

Dr. Everhart is a Professor at the iSchool, Florida State University, USA.

Sometimes prospective doctoral students believe that their new doctoral level courses will be just like the ones in their master's degree. However, this is far from the truth. Doctoral studies are seminar based where students take on much of the presentation of materials and discussions. Readings are always focused on research and discussions of personal experience and "How I did it good" are not rewarded.

- What is the purpose of a doctoral degree?

- What goes on in doctoral level courses?

- Are you ready for this new approach to teacher-librarian studies?

- Can you accept being openly challenged and even criticized?

- Are you a self-starter and a self-motivator?

\section{PhD Topic Selection}

Ross J. Todd

Dr. Todd is Associate Professor and Chair, Department of Library and Information Science, School of Communication and Information, Rutgers University, USA.

For many embarking on doctoral studies, this is the starting point of a long academic career. It is often the building block for a sustained research career, so getting the focus / research problem is very important. As you think through potential topics, ask first:

- So what? Does it matter if no one ever knows about this?

- What is the value-added for your research?

- How will it contribute to the social good?

- How will it stand the time test?

- What is its relevance beyond the immediate context of the research?

- How can my research demonstrate thought leadership for years to come?

- Will it motivate you in the same way in three plus years?

Begin to ask and answer these questions early in your planning process. Craft an elevator speech early on to test your ideas on others - be humble, flexible and patient as you listen to the ideas of others. This will also help you choose something manageable, and set realistic boundaries. I remember my dissertation supervisor, following my exuberant outline of my proposed dissertation, asking me: "Now after you complete these 10 dissertations, what are your plans?" It is probably the most common piece of advice I give current doctoral students! 